\title{
Vancomycin dosing in patients undergoing maintenance hemodialysis
}

\author{
Aleksandra Rymarz • Dorota Brodowska-Kania • \\ Małgorzata Gomółka • Elżbieta Józefczak-Bergier • \\ Małgorzata Dzierżanowska $\cdot$ Stanisław Niemczyk
}

Received: 2 February 2014/ Accepted: 24 March 2014/Published online: 3 April 2014

(C) The Author(s) 2014. This article is published with open access at Springerlink.com

\section{Editor,}

In recent years, increasing pathogen resistance for vancomycin has been observed. According to new recommendations, trough target levels for this drug should be between 15 and $20 \mu \mathrm{g} / \mathrm{ml}$ [1]. Concentrations lower than $10 \mu \mathrm{g} / \mathrm{ml}$ can cause therapeutic failure and bring about vancomycin resistance [2]. To achieve this target, an initial dose of $20-25 \mathrm{mg} / \mathrm{kg}$ actual body weight is recommended for all patients.

We examined 22 patients ( 5 female, 17 male), age $64.32 \pm 12.2$ years, being treated with hemodialysis for end-stage renal disease between 2011 and 2012. The study protocol was approved by the Ethics Committee of Military Institute of Medicine. All patients were treated using a lowflux dialyzer of varying sizes three times a week for 3-4 h. Vascular accesses were as follows: cuffed catheters (16 patients), noncuffed catheters (five patients) and arteriovenous fistula (one patient). Each patient received an initial dose of vancomycin $20 \mathrm{mg} / \mathrm{kg}$ actual dry body weight, rounded by $250 \mathrm{mg}$ with an infusion rate $10 \mathrm{mg} / \mathrm{min}$ after dialysis session. Vancomycin trough levels were determined twice: 4 days after the initial dose and 4 days after the second dose. The second dose was related to plasma vancomycin concentration. If vancomycin concentration was at target level $(15-20 \mu \mathrm{g} / \mathrm{ml})$, the same dose was

A. Rymarz $(\varangle)$ · D. Brodowska-Kania · M. Gomółka ·

S. Niemczyk

Department of Internal Diseases, Nephrology and Dialysis,

Military Institute of Medicine, Szaserów 128, 04-141 Warsaw,

Poland

e-mail: ola@rymarz.pl; arymarz@wim.mil.pl

E. Józefczak-Bergier · M. Dzierżanowska

Department of Laboratory Diagnostics, Military Institute of

Medicine, ul. Szaserów 128, 04-141 Warsaw, Poland repeated. If concentration was lower than $15 \mu \mathrm{g} / \mathrm{ml}$, the second dose was increased by $30 \%$. If vancomycin concentration exceeded $20 \mu \mathrm{g} / \mathrm{ml}$, a reduced dose was administered. Fluorescence polarization immunoassay test (Axsym system, Abbott) was used to assess plasma vancomycin concentration.

The main reason for vancomycin administration was sepsis ( 20 patients, $90.9 \%$ ), in all cases related to catheter. The most frequent pathogen was methicillin resistant Staphylococcus aureus (13 patients, $72.2 \%$ ).

Mean trough vancomycin concentration after the initial dose was $13.26 \pm 4.46 \mu \mathrm{g} / \mathrm{ml}$. Mean vancomycin dose per actual body weight was $20.62 \pm 2.35 \mathrm{mg} / \mathrm{kg}$. Mean first total dose was $1,590.91 \pm 342.98 \mathrm{mg}$. Six patients $(27.2 \%)$ achieved target trough levels of $15-20 \mu \mathrm{g} / \mathrm{ml}$. Range $10-20 \mu \mathrm{g} / \mathrm{ml}$ achieved $72.7 \%$ (16 patients). 15 patients $(68.1 \%)$ had trough levels below $15 \mu \mathrm{g} / \mathrm{ml}$, among them six patients (27.2\%) had levels below $10 \mu \mathrm{g} /$ $\mathrm{ml}$. Only one patient had concentration above 20 $(21.42 \mu \mathrm{g} / \mathrm{ml})$.

After the second dose, the mean trough level of this drug was $20.73 \pm 4.58 \mu \mathrm{g} / \mathrm{ml}$. Mean vancomycin dose per actual body weight was $23.01 \pm 10.11 \mathrm{mg} / \mathrm{kg}$. Mean total second dose was $1,777.78 \pm 351.85 \mathrm{mg}$. Nine patients (40.9\%) had trough levels of $15-20 \mu \mathrm{g} / \mathrm{ml}$. Two patients had trough levels below $15 \mu \mathrm{g} / \mathrm{ml}$, and no one fell below $10 \mu \mathrm{g} / \mathrm{ml}$. Eleven patients (50\%) had concentration above $20 \mu \mathrm{g} / \mathrm{ml}$, among them mean concentration was $23.42 \mu \mathrm{g} /$ $\mathrm{ml}$.

Initial vancomycin doses in hemodialysis patients should be based on actual body weight; however, one-third of patients do not reach the recommended trough level of $15-20 \mu \mathrm{g} / \mathrm{ml}$. It seems reasonable that among certain patients higher doses could be used. Subsequent doses of the drug should be related to its serum concentration, type 
of membrane used in dialysis session and time of its administration. Vancomycin dosing protocol in hemodialysis patients requires further evaluation on larger groups of patients.

Acknowledgments All authors of manuscript declare no conflict of interest. All authors agree with the content of manuscript. The paper has not been published or submitted for publication elsewhere. The protocol for the research has been approved by the Ethics Committee of Military Institute of Medicine.

Open Access This article is distributed under the terms of the Creative Commons Attribution License which permits any use, distribution, and reproduction in any medium, provided the original author(s) and the source are credited.

\section{References}

1. Rybak MJ, Lomaestro BM, Rotscahfer JC et al (2009) Vancomycin therapeutic guidelines: a summary of consensus recommendations from the Infectious Diseases Society of America, the American Society of Health-System Pharmacists and the Society of Infectious Diseases Pharmacists. Clin Infect Dis 49:325-327

2. Howden BP, Ward PB, Charles PG et al (2004) Treatment outcomes for serious infection caused by methycillin-resistant Staphylococcus aureus with reduced vancomycin susceptibility. Clin Infect Dis 38:521-528 